\title{
Velvet Bentgrass and Creeping Bentgrass Growth, Rooting, and Quality with Different Root Zone Media and Fertility Regimes
}

\author{
John Watson \\ Department of Plant Agriculture, University of Guelph, Guelph, Ontario, \\ Canada N1G 2 WI
}

François Hébert

Department of Plant Agriculture, University of Guelph, Guelph, Ontario, Canada N1G 2W1; and Ministère des Ressources naturelles et de la Faune du Québec, Direction de la recherche forestière, 2700 rue Einstein, SainteFoy, Quebec, G1P 3W8 Canada

Eric M. Lyons, Theo Blom, and Katerina S. Jordan ${ }^{1}$

Department of Plant Agriculture, University of Guelph, Guelph, Ontario, Canada N1G 2W1

Additional index words. Agrostis canina, nitrogen, phosphorus, greenhouse, cumulative shoot dry weight, root:shoot ratio

Abstract. Two complementary greenhouse studies were conducted to examine the effects of different root zones and fertilization regimes on 'SR7200' velvet bentgrass (Agrostis canina L.) and L-93 creeping bentgrass (Agrostis stolonifera L.). In the first study, in which only velvet bentgrass was studied, peat content in the root zone mixture contributed significantly to initial establishment of this species and high seeding rates increased cumulative shoot dry weight early in establishment but became less significant as the turfgrass matured. Higher phosphorus rates contributed to increased cumulative shoot dry weight over the first 4 weeks of the experiment. Nitrogen rate was the most significant factor positively affecting both cumulative shoot dry weight and turfgrass quality. In the second experiment with both velvet bentgrass and creeping bentgrass, nitrogen rate significantly increased turfgrass quality when measured at Week 5 , halfway through the experiment. Over time, however, turf growth and quality were negatively impacted in both species with increasing nitrogen rates. Root zone composition had a significant effect on initial establishment of both bentgrasses with greater peat content leading to higher quality early on. Cumulative shoot dry weight increased with increasing nitrogen rate but at higher rates, there was a concomitant decrease in root production.

Establishment and management practices for creeping bentgrass (Agrostis stolonifera L.) are well understood as a result of its widespread popularity and use (Beard, 1973, 2002; Christians, 1998). Newer generations of creeping bentgrass cultivars require regular applications of both fertilizers and fungicides to maintain acceptable putting green quality (Dernoeden, 2002). With increasing pesticide restrictions coming from legislation at various government levels (Burrows, 2002; Cousineau, 2002; Gerretsen, 2008) and, more recently, with the restriction of fertilizer use in turf

\footnotetext{
Received for publication 20 Sept. 2011. Accepted for publication 9 Dec. 2011.

Special thanks go to Alex Porter and Ken Carey for technical assistance, the Ontario Turfgrass Research Foundation and the Natural Sciences and Engineering Research Council for funding, and Cliff Beninger for assistance in manuscript preparation.

${ }^{1}$ To whom reprint requests should be addressed; e-mailkjordan@uoguelph.ca.
}

(Throssel et al., 2009), it is necessary to seek new approaches to achieve high-quality turfgrass systems.

Lower input species such as velvet bentgrass (Agrostis canina L.) could be an alternative to creeping bentgrass as a result of higher disease resistance (Brilman and Meyer, 2000) and superior putting surface quality (Moneith and Welton, 1932). Recently velvet bentgrass has been found to maintain acceptable quality in low-input golf course fairways subjected to two mowing heights and three levels of traffic (Watkins et al., 2010). However, establishment and management practices for this species have not been extensively studied and the limited research has focused primarily on older varieties of velvet bentgrass selected from South German mixed bentgrasses (DeFrance et al., 1952; North and Odland, 1934; Skogley, 1975; Sprague and Evaul, 1930).

Proper nitrogen fertilization is essential not only to turfgrass establishment (Kaminski et al., 2004; White, 2003), growth, and development, but also to recovery from physical stresses and damage from pests like Sclerotinia homoeocarpa F.T. Bennett, the causal agent of dollar spot (Beard 1973, 2002; Markland et al., 1969). Nitrogen application rate is also a significant contributor to other turfgrass qualities such as aesthetics and functional characteristics (e.g., ball roll speed and distance) (Johnson et al., 2003). However, applying nitrogen above the requirements of the specific species or cultivar in question can result in increased aboveground growth (Christians et al., 1979; Markland and Roberts, 1969), increased thatch levels (Cavanaugh et al., 2011), and lead to increased frequency of mowing. Furthermore, excess nitrogen may also reduce root depth and density (Bowman et al., 1998; Schlossberg and Karnok, 2001) and nutrient uptake (Bowman et al., 1998).

Three additional factors that can impact turfgrass establishment are root zone mixture, seeding rate, and phosphorus fertility. Murphy et al. (2001) found that smaller particle-sized sands result in good establishment of creeping bentgrass and a later study by the same author (Murphy et al., 2005) as well as one by Bigelow et al. (2001) found that increasing the amount of organic amendments in the root zone improves the rate of turfgrass establishment. Peat contains humic acid, which potentially enhances establishment (Cooper et al., 1998). The recommended seeding rate for velvet bentgrass in Ontario is $0.5-0.8 \mathrm{~kg} / 100 \mathrm{~m}^{2}$ (Ontario Ministry of Agriculture, Food and Rural Affairs, 2005), but the background for this rate may be empirical (Paré, 2004). Finally, established velvet bentgrass grows better at high phosphorous levels in the root zone (Miles, 1974), but no data are available for the phosphorous rate at establishment.

Two complementary controlled environment studies were conducted to determine the effect of these various factors on the growth of velvet bentgrass. The objective of the first study was to examine different establishment inputs for 'SR7200' velvet bentgrass. It was hypothesized that velvet bentgrass would respond positively to 1) increasing peat content of the root zone mixture; 2) increasing seeding rate; 3 ) increasing phosphorus application rate; and 4) increasing nitrogen application rate. The second study expanded on the first one to include creeping bentgrass. The objective of that study was to examine the effect of nitrogen rate on both velvet and creeping bentgrass grown on either an 80:20 (sand:peat, v:v) or a $100 \%$ sand simulated root zone profile. It was hypothesized that increased nitrogen rates would improve turfgrass quality, that 'SR7200' velvet bentgrass would be more responsive to nitrogen than 'L-93' creeping bentgrass, and that the optimal nitrogen rate for an 80:20 (sand:peat) root zone would be lower than a $100 \%$ sand root zone for both species.

\section{Material and Methods}

Study 1: Establishment of 'SR7200' velvet bentgrass

Experimental conditions. A 10-week project was conducted during the winter of 2006 in a glass greenhouse at the Edmund C. Bovey 
Building, University of Guelph, Guelph,

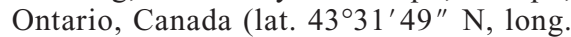
$\left.80^{\circ} 13^{\prime} 34^{\prime \prime} \mathrm{W}\right)$. The average daily minimum and maximum temperatures were 16.8 and $24.0^{\circ} \mathrm{C}$, respectively, with an average relative humidity of $57 \%$ and a global outside radiation of $260 \mathrm{~W} \cdot \mathrm{m}^{-2}$ (Argus Control Systems Limited, British Columbia, Canada). Supplemental lighting was provided by high-pressure sodium lamps at $80 \mu \mathrm{mol} \cdot \mathrm{m}^{-2} \cdot \mathrm{s}^{-1}$ whenever outside radiation was below $150 \mathrm{~W} \cdot \mathrm{m}^{-2}$. Photoperiod was set at $16 \mathrm{~h}$.

Experimental design. The study explored the effects of four root zone mixtures [100:0, 95:5, 80:20, and 70:30 sand:peat (v:v)], three seeding rates $\left(5,10\right.$, or $\left.15 \mathrm{~g} \cdot \mathrm{m}^{-2}\right)$, two nitrogen treatments ( 5 and $10 \mathrm{~g} \mathrm{~N} / \mathrm{m}^{2}$ for Weeks $1-4$ and weekly applications of 0.25 and 0.75 g N/m $\mathrm{m}^{2}$ week during Weeks 5-9), and three phosphorous rates $\left(2.5,7.5\right.$, and $12.5 \mathrm{~g} \mathrm{P}_{2} \mathrm{O}_{5} /$ $\mathrm{m}^{2}$ for Weeks 1-4 and weekly applications of $0.0,0.19$, and $0.38 \mathrm{~g} \mathrm{P}_{2} \mathrm{O}_{5} / \mathrm{m}^{2} /$ week during Weeks 5-9) on the establishment and growth of velvet bentgrass. The study was set up as a four-way factorial and all treatments were replicated four times in a randomized complete block design.

Treatment application. Velvet bentgrass 'SR7200' was seeded in square greenhouse pots measuring $10 \mathrm{~cm}$ length $\times 10 \mathrm{~cm}$ width $\times$ $13 \mathrm{~cm}$ depth. Before seeding, a starter fertilizer consisting of microprilled urea $(46 \mathrm{~N}-0 \mathrm{P}-0 \mathrm{~K})$ (size 100-130), di-ammonium phosphate (18N$46 \mathrm{P}-0 \mathrm{~K})$, and potassium sulfate $(0 \mathrm{~N}-0 \mathrm{P}-50 \mathrm{~K})$ was applied to the surface of each pot at the nitrogen and phosphorus levels needed for each treatment application. From Week 5 to Week 9, the fertilizer treatments were implemented by dissolving the nutrients in a liquid solution and adding them to the pots at $50 \mathrm{~mL}$ per pot on a weekly basis. The nitrogen and phosphorus solutions were prepared using $\mathrm{NH}_{4} \mathrm{NO}_{3}$ and $\mathrm{KH}_{2} \mathrm{PO}_{4}$, respectively, in deionized water (Beard, 2002; White, 2003).

Plant culture. After seeding, pots were irrigated with deionized water using automated misters for two weeks and then manually thereafter. At Week 3, a preventive fungicide spray was applied using iprodione (Rovral ${ }^{\mathrm{TM}}$ $50 \mathrm{WP}$ ) at a rate of $1.8 \mathrm{~g} \cdot \mathrm{m}^{-2}$ to all experimental units to control fusarium in the greenhouse. Starting at Week 4, the turf was mowed twice per week to a height of $12.5 \mathrm{~mm}$. Harvested clippings were subsequently dried for 72-96 h at $60{ }^{\circ} \mathrm{C}$ in a forced-air dryer (Blue M Industrial Oven, New Columbia, PA) and dry weight was determined.

Data collection. In addition to dry weight, turfgrass cover was visually rated on a scale of 0 (bare soil) -100 (no soil visible). Visual ratings of turfgrass quality and color were made on a scale of 1-9 based on the National Turfgrass Evaluation Program protocol (Morris, undated).

Data analysis. Data were analyzed using the PROC MIXED procedure in SAS (Version 9.1.3; SAS Institute, Cary, NC). An analysis of residuals was also performed on all data to confirm that the assumptions of analysis of variance were satisfied (Bowley, 2008). Means separations were performed using the Tukey-Kramer test with the Type I error rate set at $\alpha=0.05$.

\section{Study 2: Nitrogen rate and root zone construction for establishment of two species of bentgrass}

Experimental conditions. This study focused on two root zones (100:0 and 80:20 sand:peat mixtures) and six nitrogen rates (0.12, 0.24, 0.48, 0.96, 1.9, $2.8 \mathrm{~g} \mathrm{~N} / \mathrm{m}^{2} /$ week, roughly equivalent to annual nitrogen rates of $0.25,0.50,1.0,2.0,4.0$, and $6.0 \mathrm{~kg} / 100 \mathrm{~m}^{2}$, respectively) and was expanded to include two bentgrass species (velvet bentgrass 'SR7200' and creeping bentgrass 'L-93'). Treatments were arranged as a three-way factorial in a completely randomized design with four replications for a total of 96 experimental units. The study was conducted over an 11-week period from January through March of 2007 and took place in the same greenhouse with the same growing parameters as Study 1 .

Treatment application. Velvet bentgrass 'SR7200' and creeping bentgrass 'L-93' were seeded at a rate of $6 \mathrm{~g} \cdot \mathrm{m}^{-2}$ into one of two root zone mixtures [100:0 or 80:20 (sand:peat, v:v)]. The growing containers were $8 \mathrm{~cm}$ (i.d.) polyvinyl chloride (PVC) irrigation pipes at a length of $40.5 \mathrm{~cm}$ (United States Golf Association Green Section Staff, 1993) as described in O'Connor (2009). Growing containers were changed from Study 1 to include the collection of root data. The sphagnum peatmoss and calcareous sand were commercially obtained (Hutcheson Sand and Mixes, Huntsville, Ontario, Canada). The columns were prewatered to field capacity before seeding.

Nitrogen treatments were applied as urea for the duration of the project. During the first 2 weeks, $1.5 \mathrm{~g}$ of $\mathrm{P}_{2} \mathrm{O}_{5}$ and $1.5 \mathrm{~g}$ of $\mathrm{K}_{2} \mathrm{O} / \mathrm{m}^{2} /$ week were applied to all treatments. In addition, a micronutrient mixture was applied during seeding at the concentrations summarized in Table 1, the levels of which were based on those used by Hoagland and Arnon (1938) and McCrimmon et al. (1992). All fertilizers were dissolved in deionized water and applied in 50-mL aliquots per column.

Plant culture. Cultural practices were similar to those in the first study. The misting cycle was adjusted to account for the higher solar radiation and temperature in the greenhouse. The columns were brought to field capacity one time each week.

Data collection. The turf was trimmed with scissors to 5 -mm height two times per week starting in Week 3 , and clippings were weighed for both fresh and dry weight following the same procedure as Study 1. Visual ratings of turf quality and color were made on a weekly basis similar to Study 1. Total root mass was determined by sectioning each column at four different depths: $0-5 \mathrm{~cm}, 5-10 \mathrm{~cm}, 10-20 \mathrm{~cm}$, and $20+\mathrm{cm}$ at the end of the experiment (Week 10). The root sectioning process involved removing the entire root zone column (intact) from the PVC tube, sectioning the column to the prescribed depths using a sharp knife, and placing each section in a freezer bag for storage at $4{ }^{\circ} \mathrm{C}$. Roots were removed from each section by gently washing under an aerated stream of water above a standard 1-mm sieve to prevent root losses. Roots were then dried for $96 \mathrm{~h}$ at $70{ }^{\circ} \mathrm{C}$ in a convection laboratory dryer (Fisher Scientific Company, Ottawa, Ontario, Canada). Samples were transferred directly from the dryer to a desiccator and weighed. Root-toshoot ratio was calculated by dividing root dry weight by cumulative shoot dry weight for each sample at the end of the study.

Data analysis. The statistical analysis followed that described in Study 1. Because there were no statistically significant differences among the top three sections of the columns, the data were pooled for analysis.

\section{Results and Discussion}

\section{Study 1}

Cumulative shoot dry weight. Over the first 4 weeks of the study, cumulative shoot dry weight increased with increasing phosphorus rate, peat content, and seeding rate, although the effect of seeding rate was less pronounced as peat content in the root zone decreased (data not shown). The positive effect of peat content on velvet bentgrass growth was expected as a result of the species' superior growth characteristics in peat-filled heaths (Miles, 1974). Both Bigelow et al. (2001) and Murphy et al. (2005) attributed better establishment of 'L-93' creeping bentgrass in high peat content root zones to increased water retention and increased cation exchange capacity so it is likely that this is the case with velvet bentgrass as well. Phosphorus application rate was significantly and positively correlated with cumulative shoot dry weight of velvet bentgrass between the 2.5 and $7.5 \mathrm{~g} \mathrm{P}_{2} \mathrm{O}_{5} / \mathrm{m}^{2}$ rates but above the $7.5 \mathrm{~g} \mathrm{P}_{2} \mathrm{O}_{5} / \mathrm{m}^{2}$ rate, there was no further increase. Nitrogen rate had no significant effect on shoot dry weight during the first portion of the study regardless of root zone composition.

Table 1. Supplemental nutrient concentrations used in Study 2 and applied in one application at seeding.

\begin{tabular}{lcl}
\hline Micronutrient & Concn delivered $\left(\mathrm{mg} \cdot \mathrm{L}^{-1}\right)$ & \multicolumn{1}{c}{ Compounds used } \\
\hline Calcium (Ca) & 36.0 & $\mathrm{CaCl}_{2} \cdot 2 \mathrm{H}_{2} \mathrm{O}$ \\
Sulfur (S) & 23.8 & $\mathrm{MgSO}_{4} \cdot 7 \mathrm{H}_{2} \mathrm{O}, \mathrm{CuSO}_{4} \cdot 5 \mathrm{H}_{2} \mathrm{O}, \mathrm{ZnSO}_{4} \cdot 7 \mathrm{H}_{2} \mathrm{O}$ \\
Magnesium (Mg) & 18.0 & $\mathrm{MgSO}_{4} \cdot 7 \mathrm{H}_{2} \mathrm{O}$ \\
Iron (Fe) & 2.0 & $13.2 \% \mathrm{Fe}-\mathrm{EDTA}$ \\
Manganese (Mn) & 0.50 & $\mathrm{MnCl}_{2} \cdot 4 \mathrm{H}_{2} \mathrm{O}$ \\
Boron (B) & 0.25 & $\mathrm{H}_{3} \mathrm{BO}_{3}$ \\
Copper (Cu) & 0.02 & $\mathrm{CuSO}_{4} \cdot 5 \mathrm{H}_{2} \mathrm{O}$ \\
Zinc (Zn) & 0.05 & $\mathrm{ZnSO}_{4} \cdot 7 \mathrm{H}_{2} \mathrm{O}$ \\
Molybdenum (Mo) & 0.01 & $\mathrm{H}_{2} \mathrm{MoO}_{4}$ \\
Chloride (Cl) & 64.3 & $\mathrm{CaCl}_{2} \cdot 2 \mathrm{H}_{2} \mathrm{O}, \mathrm{MnCl}_{2} \cdot 4 \mathrm{H}_{2} \mathrm{O}$
\end{tabular}


Results over Weeks 5 to 9 revealed different trends from those taken during Weeks 1 to 4 . By the fifth week of the study, seeding rate no longer had an effect on shoot weight (data not shown). It is common to seed newer cultivars of creeping bentgrass between 0.5 and $0.8 \mathrm{~kg} / 100 \mathrm{~m}^{2}$ (Murphy et al., 2005; Vavrek, 1999) and the results of this study suggest that this rate is acceptable for velvet bentgrass. The reduced effect of seeding rate on shoot growth beyond the initial establishment phase suggests it might not be worth the cost to seed above $5 \mathrm{~g} \cdot \mathrm{m}^{-2}\left(0.5 \mathrm{~kg} / 100 \mathrm{~m}^{2}\right)$ because over time, turf cover and growth are affected very little by initial seeding rate. Differences in root zone composition still existed but were observed only at the higher nitrogen rates and only between the two lower percentage peat mixtures and two higher percentage peat mixtures (Table 2). There were also interactions between phosphorus and nitrogen. At the higher nitrogen rate $(0.75 \mathrm{~g}$ $\mathrm{N} / \mathrm{m}^{2} /$ week), cumulative dry weight was reduced in the treatments with no added phosphorus, but at the low nitrogen rate, the effect of phosphorus addition was not evident. These results suggest that nitrogen rate has the most influential effect on cumulative dry weight.

Turfgrass color. Turfgrass color increased significantly with increasing nitrogen rate (Table 2) and a phosphorus rate-by-nitrogen rate interaction was present for all root zones. There was no effect of phosphorus on color at the higher nitrogen rate, but color was rated higher with no phosphorus than with the other two phosphorus treatments at the low nitrogen rate. Waddington et al. (1978) observed that creeping bentgrass grown with low phosphorus exhibits greater color intensity in the leaves than creeping bentgrass grown with high phosphorus. An interaction between nitrogen rate and root zone composition also existed with turfgrass color. At the higher nitrogen rate, color ratings were increased in the two high peat root zones compared with all sand but at the low nitrogen rate color, ratings were higher in the two low-peat root zones. Like with shoot dry weight, nitrogen rate was the most significant contributor to turfgrass color with the high rate producing the best color (Table 2).

Turfgrass quality. Seeding rate, phosphorus rate and nitrogen rate significantly affected turfgrass quality over the second phase of the experiment (Table 3). Although seeding rate did not significantly influence cumulative dry weight in the latter half of the study, the quality of velvet bentgrass did increase with increasing seeding rate throughout the study. The effects of phosphorus on turfgrass quality mimicked those on cumulative shoot dry weight in that there was no significant effect after initial establishment. These results support data presented by Johnson et al. (2003) that only a small amount of phosphorus fertilization is necessary to maintain turfgrass quality and tissue levels in established creeping bentgrass and that once a small amount of phosphorus is available in the root zone, additional applications are not necessary. We expected velvet bentgrass to perform best with

Table 2. The interactive effects of root zone, nitrogen rate, and phosphorus rate on the weekly cumulative shoot dry weight and turfgrass color of 'SR7200' velvet bentgrass during establishment (Weeks 5-9).

\begin{tabular}{lccc}
\hline Nitrogen $\left(\mathrm{g} / \mathrm{m}^{2} /\right.$ week) & Root-zone (sand:peat v:v) & Cumulative shoot dry wt $\mathrm{z}^{\mathrm{z}}$ & Turfgrass color \\
\hline 0.75 & $70: 30$ & $86.1 \mathrm{a}^{\mathrm{y}}$ & $8.4 \mathrm{a}^{\mathrm{v}}$ \\
0.75 & $80: 20$ & $88.4 \mathrm{a}$ & $8.4 \mathrm{a}$ \\
0.75 & $95: 50$ & $76.2 \mathrm{~b}$ & $8.1 \mathrm{ab}$ \\
0.75 & $100: 0$ & $68.8 \mathrm{~b}$ & $8.0 \mathrm{~b}$ \\
0.25 & $70: 30$ & $27.8 \mathrm{c}$ & $6.2 \mathrm{~d}$ \\
0.25 & $80: 20$ & $30.2 \mathrm{c}$ & $6.4 \mathrm{~cd}$ \\
0.25 & $95: 50$ & $30.0 \mathrm{c}$ & $6.6 \mathrm{c}$ \\
0.25 & $100: 0$ & $30.3 \mathrm{c}$ & $6.6 \mathrm{c}$
\end{tabular}

\begin{tabular}{lccc} 
Nitrogen $\left(\mathrm{g} / \mathrm{m}^{2} /\right.$ week $)$ & Phosphorus $\left(\mathrm{g} / \mathrm{m}^{2} /\right.$ week $)$ & Cumulative shoot dry wt & Turfgrass color \\
\hline 0.75 & 0.00 & $68.7 \mathrm{~b}$ & $8.4 \mathrm{a}$ \\
0.75 & 0.19 & $83.0 \mathrm{a}$ & $8.2 \mathrm{a}$ \\
0.75 & 0.38 & $88.0 \mathrm{a}$ & $8.1 \mathrm{a}$ \\
0.25 & 0.00 & $30.1 \mathrm{c}$ & $6.9 \mathrm{~b}$ \\
0.25 & 0.19 & $28.5 \mathrm{c}$ & $6.3 \mathrm{c}$ \\
0.25 & 0.38 & $30.2 \mathrm{c}$ & $6.1 \mathrm{c}$ \\
& & & \\
ANOVA & & $* *$ & $\mathrm{NS}$ \\
Root zone & & $\mathrm{NS}$ & $* *$ \\
Seeding rate & & $* *$ & $* *$ \\
Phosphorus & $* *$ & $* *$ \\
Nitrogen & & $\mathrm{NS}$ & $*$ \\
Root zone*seeding rate & & $\mathrm{NS}$ & $* *$ \\
Root zone*phosphorus & & $* *$ & $*$ \\
Root zone*nitrogen & & $\mathrm{NS}$ & $\mathrm{NS}$ \\
Seeding rate*phosphorus & & $\mathrm{NS}$ & $* *$ \\
Seeding rate*nitrogen & & $* *$ & \\
Phosphorus*nitrogen & & & \\
\hline
\end{tabular}

${ }^{2}$ Cumulative shoot dry weight $=\mathrm{mg}$ of dried turfgrass clippings/pot.

${ }^{y}$ Cumulative shoot dry weights within the column followed by the same letter grouping are not significantly different $(P>0.05)$ by the Tukey-Kramer method.

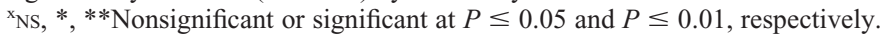

ANOVA $=$ analysis of variance.

increasing phosphorus rate based on its presence in the natural environment under high phosphorus conditions (Miles, 1974), but overall phosphorus is less important and nitrogen appears to be the greatest contributing factor to turfgrass quality. The high nitrogen rate of $0.75 \mathrm{~g} \mathrm{~N} / \mathrm{m}^{2} /$ week significantly increased turfgrass quality compared with the low treatment of $0.25 \mathrm{~g} \mathrm{~N} / \mathrm{m}^{2} /$ week for all treatment combinations.

\section{Study 2}

Cumulative shoot dry weight. Nitrogen rate, root zone mixture, and turfgrass species influenced cumulative shoot dry weight throughout the experiment (Fig. 1). As was observed in Study 1 , at the lower nitrogen rates $(0.12$, 0.24 , and $0.48 \mathrm{~g} \mathrm{~N} / \mathrm{m}^{2} /$ week), there was no effect of root zone media, but there was increased cumulative shoot dry weight in the $80: 20$ root zone media at the three highest nitrogen rates compared with the $100 \%$ sand root zone media. Cumulative shoot dry weight was lowest in velvet bentgrass on the $100 \%$ sand root zone and highest for creeping bentgrass on the 80:20 root zone. Cumulative shoot dry weight increased with nitrogen rate until the $1.9 \mathrm{~g} \mathrm{~N} / \mathrm{m}^{2} /$ week rate and then leveled off. At rates of $0.96 \mathrm{~g} \mathrm{~N} / \mathrm{m}^{2} /$ week and greater, there was significantly greater shoot

Table 3. The interactive effects of seeding rate, nitrogen rate, and phosphorus rate on weekly turfgrass quality ratings of 'SR7200' velvet bentgrass for the establishment grow-in phase (Weeks 5-9).

\begin{tabular}{|c|c|c|}
\hline $\begin{array}{l}\text { Nitrogen } \\
\left(\mathrm{g} / \mathrm{m}^{2} / \text { week }\right)\end{array}$ & $\begin{array}{c}\text { Seeding } \\
\text { rate }\left(\mathrm{g} \cdot \mathrm{m}^{-2}\right)\end{array}$ & $\begin{array}{l}\text { Turfgrass } \\
\text { quality }^{z}\end{array}$ \\
\hline 0.25 & 5 & $6.1 \mathrm{e}^{\mathrm{y}}$ \\
\hline 0.75 & 5 & $7.4 \mathrm{c}$ \\
\hline 0.25 & 10 & $6.3 \mathrm{e}$ \\
\hline 0.75 & 10 & $7.9 \mathrm{~b}$ \\
\hline 0.25 & 15 & $6.7 \mathrm{~d}$ \\
\hline 0.75 & 15 & $8.3 \mathrm{a}$ \\
\hline $\begin{array}{l}\text { Nitrogen } \\
\left(\mathrm{g} / \mathrm{m}^{2} / \text { week }\right)\end{array}$ & $\begin{array}{l}\text { Phosphorus } \\
\left(\mathrm{g} / \mathrm{m}^{2} / \text { week) }\right.\end{array}$ & $\begin{array}{c}\text { Turfgrass } \\
\text { quality }\end{array}$ \\
\hline 0.75 & 0.00 & $7.8 \mathrm{a}$ \\
\hline 0.75 & 0.19 & $7.9 \mathrm{a}$ \\
\hline 0.75 & 0.38 & $7.9 \mathrm{a}$ \\
\hline 0.25 & 0.00 & $6.7 \mathrm{c}$ \\
\hline 0.25 & 0.19 & $6.2 \mathrm{c}$ \\
\hline 0.25 & 0.38 & $6.1 \mathrm{c}$ \\
\hline \multicolumn{3}{|l|}{ ANOVA $^{x}$} \\
\hline Root zone & & $*$ \\
\hline Seeding rate & & $* *$ \\
\hline Phosphorus & & $* *$ \\
\hline Nitrogen & & $* *$ \\
\hline Root zone*seeding rate & & NS \\
\hline Root zone*phosphorus & & $* *$ \\
\hline Root zone*nitrogen & & $*$ \\
\hline $\begin{array}{l}\text { Seeding } \\
\text { rate*phosphorus }\end{array}$ & & NS \\
\hline Seeding rate*nitrogen & & $*$ \\
\hline Phosphorus*nitrogen & & $* *$ \\
\hline
\end{tabular}

${ }^{z}$ Visual turfgrass quality rating, 1-9 scale.

${ }^{\mathrm{y}}$ Mean quality ratings within the column followed by the same letter grouping are not significantly different $(P>0.05)$ by the Tukey-Kramer method. ${ }^{\mathrm{x}} \mathrm{N}, *, * *$ Nonsignificant, significant at $P \leq 0.05$, and significant at $P \leq 0.01$, respectively.

ANOVA $=$ analysis of variance. 


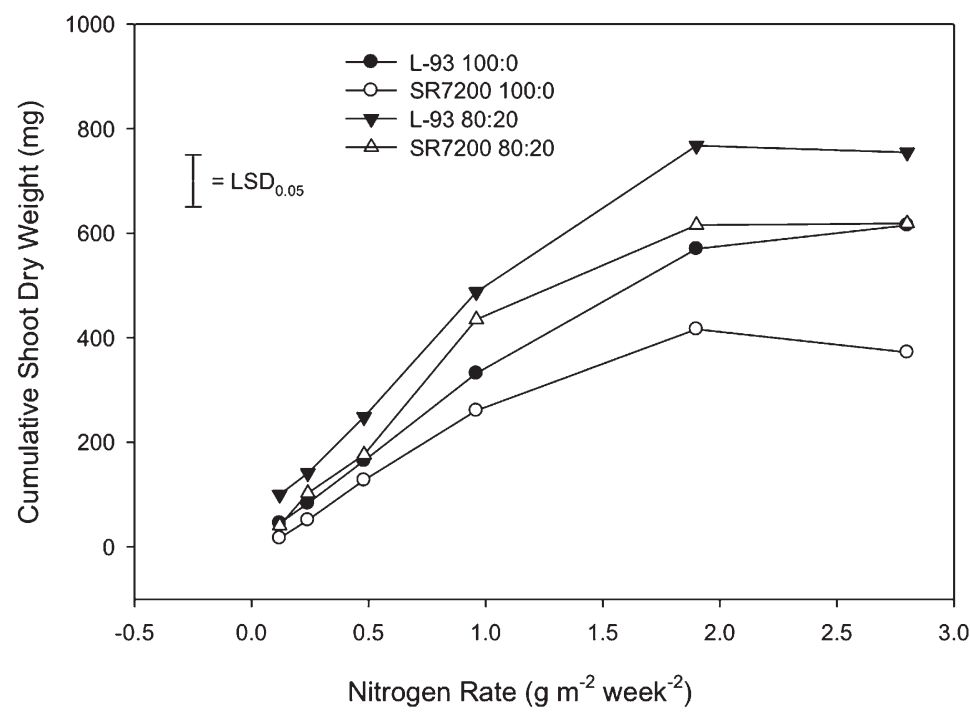

Fig. 1. The effect of nitrogen rate on cumulative shoot dry weight (from Weeks 3 to 11 inclusive) for creeping bentgrass and 'SR7200' velvet bentgrass grown on 80:20 and 100:0 (sand:peat) root zones. The vertical bars represent the Fisher's protected $\mathrm{LSD}$ value, $\mathrm{LSD}_{0.05}=99.5$. Treatment means are statistically different if they vary more than $99.5 \mathrm{mg}$. LSD = least significant difference.

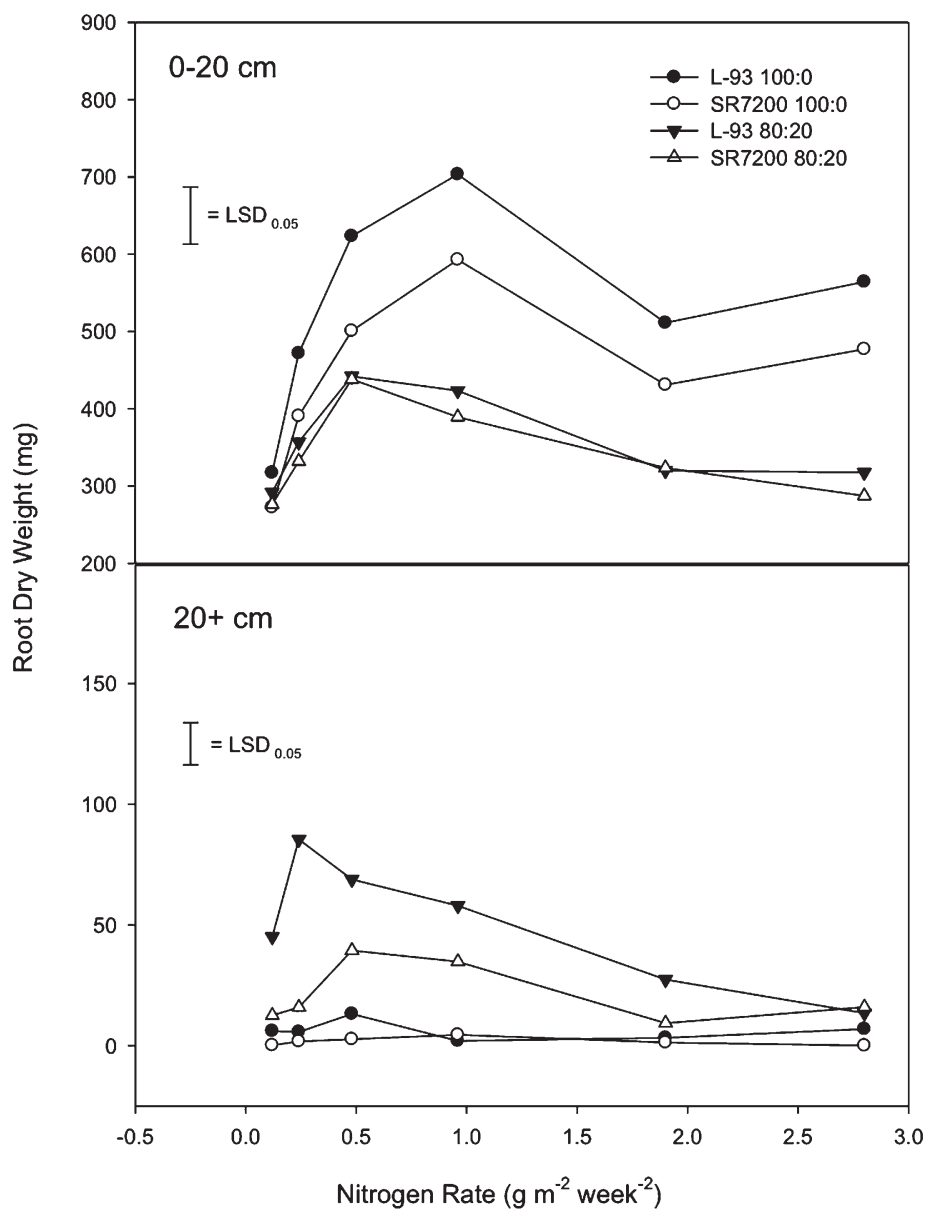

Fig. 2. The effect of nitrogen rate on total root dry mass at Week 11 for 'L-93' creeping bentgrass and 'SR7200' velvet bentgrass grown on both 80:20 and 100:0 (sand:peat) root zones. The vertical bars represent the Fisher's protected LSD value, $\mathrm{LSD}_{0.05}=73.07$ for the 0 - to $20-\mathrm{cm}$ root zone and $\mathrm{LSD}_{0.05}=$ 12.91 for the $20+$ root zone. Treatment means are statistically different if they vary more than 99.5 and $12.5 \mathrm{mg}$, respectively. LSD = least significant difference.

dry weight in both species on the $80: 20$ sand:peat mix vs. $100 \%$ sand root zone.

Results from Study 1 and Study 2 were in agreement. Both studies indicated that nitrogen rate has the greatest influence on cumulative shoot dry weight. In addition, more growth was achieved with a higher peat root zone regardless of turfgrass species. Both studies indicate that during the first few weeks of establishment, increasing nitrogen leads to significant increases in seedling vigor and subsequently turfgrass growth. Christians et al. $(1979,1981)$ found turfgrass quality of 'Penncross' creeping bentgrass is maximized at $0.048 \mathrm{~g} \mathrm{~N} / \mathrm{L}$ (in a nutrient solution) but beyond that level, aboveground growth is reduced. Our work shows an increase in growth with increasing nitrogen rate in both studies and it is likely that the highest rates used were not high enough to exhibit some of the previous trends shown by Christians et al. $(1979,1981)$.

Root dry weight. Total root dry weight was significantly affected by turfgrass species, root zone, and nitrogen rate (Fig. 2) and this trend was present at both the $0-$ to 20 - and $20+-\mathrm{cm}$ depths. Root growth in $100 \%$ sand was generally higher than in the 80:20 root zone. Root mass declined at a lower nitrogen rate $\left(0.48 \mathrm{~g} \mathrm{~N} / \mathrm{m}^{2} /\right.$ week $)$ in the $80: 20$ root zone than in the $100 \%$ sand root zone $(0.96 \mathrm{~g}$ $\mathrm{N} / \mathrm{m}^{2} /$ week). Overall, root weight in the top $20 \mathrm{~cm}$ was greater in the $100 \%$ sand root zone profile for both turfgrass species. The opposite was observed at the $20+-\mathrm{cm}$ depth where both species had significantly more roots in the $80: 20$ root zone than in the $100 \%$ sand root zone. In addition, root weight deeper than $20 \mathrm{~cm}$ decreased with increasing nitrogen rate. The trends observed for total root dry weight were consistent with those observed at the 0 - to $20-\mathrm{cm}$ depth because with both species and in both root zones, the majority of the root mass was in the shallower section. At the $20+-\mathrm{cm}$ depth, there was a three-way interaction among turfgrass species, nitrogen rate, and root zone. This interaction was likely a result of the 'L-93' creeping bentgrass having a significantly greater root mass than 'SR7200' velvet bentgrass on the $80: 20$ root zone at all but the highest nitrogen rate. This confirms that there is a difference in rooting between species with 'L-93' creeping bentgrass rooting more deeply than 'SR7200' velvet bentgrass overall.

The data on root dry weight collected in the second study exhibited a trend consistent with excess nitrogen fertilization. Beyond a nitrogen rate of $0.96 \mathrm{~g} \mathrm{~N} / \mathrm{m}^{2} /$ week, there is a decrease in root weight. These results are consistent with research on the effect of nitrogen on rooting of 'L-93' and 'Crenshaw' creeping bentgrasses by Schlossberg and Karnok (2001) and by 'Penncross' in Christians et al. (1981). Limited literature is available on velvet bentgrass rooting characteristics; however, our results suggest that 'SR7200' velvet bentgrass has shallower roots than 'L-93' creeping bentgrass. Despite this, DaCosta and Huang (2006a) have shown it is well suited to deficit irrigation practices and performs well under drought stress conditions (DaCosta and Huang, 2006b).

Turfgrass color. At both Weeks 5 and 10, color differed among turfgrass species, nitrogen rate, and root zone (data not shown). At Week 5, both species of bentgrass reached a maximum color rating of 9 , but the velvet bentgrass increased in color with increasing nitrogen rate more rapidly than creeping 


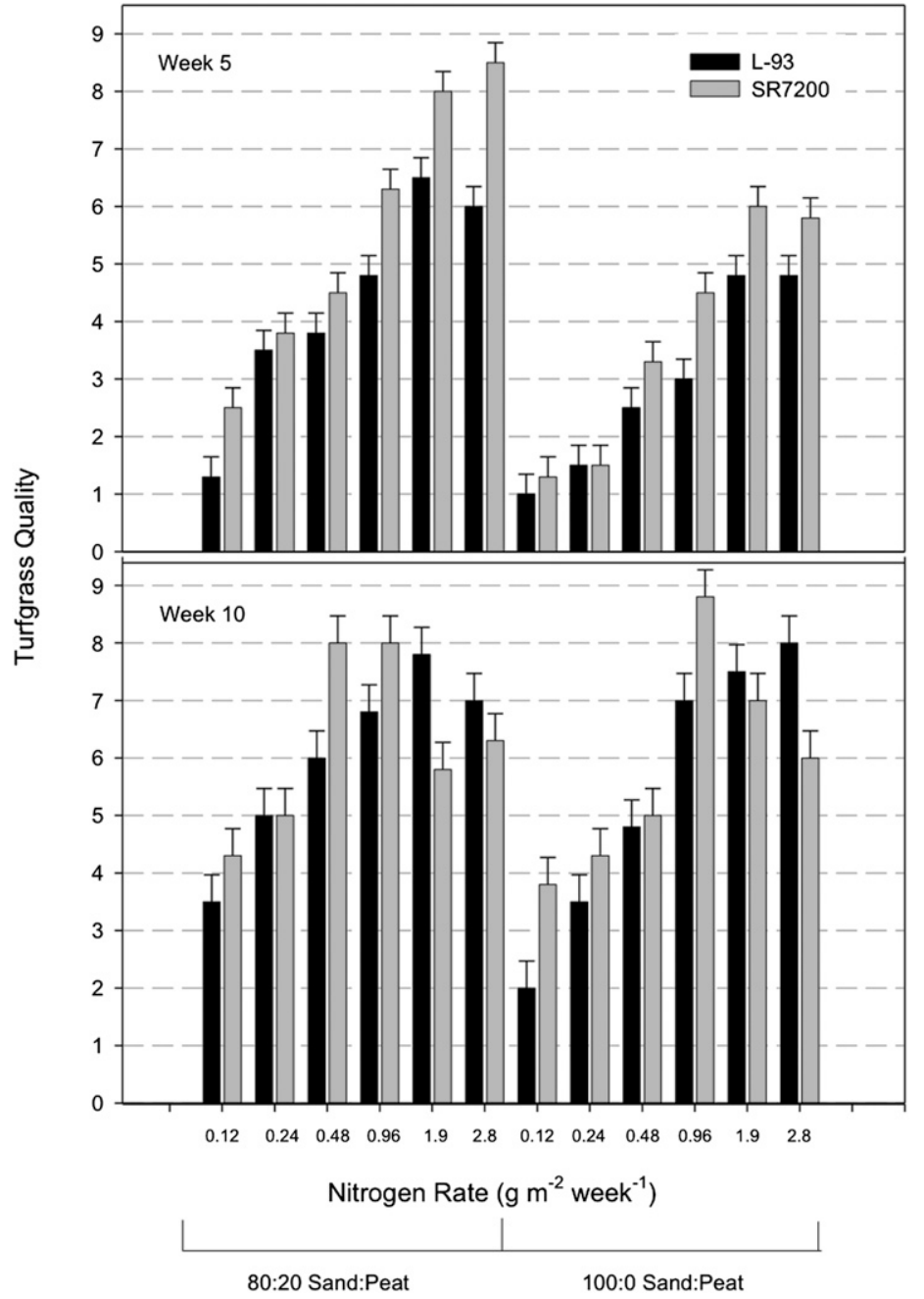

Fig. 3. The effect of nitrogen rate on turfgrass quality for 'L-93' creeping bentgrass and 'SR7200' velvet bentgrass grown in 80:20 and 100:00 sand:peat substrates. The vertical bars represent the Fisher's protected $\mathrm{LSD}$ value, $\mathrm{LSD}_{0.05}=0.35$ for Week 5 and $\mathrm{LSD}_{0.05}=0.47$ for Week 10 . Treatment means are statistically different if they vary more than 0.35 and $0.471 \mathrm{mg}$, respectively. LSD = least significant difference.

bentgrass. Madison (1962) examined the effect of nitrogen rate on established creeping bentgrass and found that increasing rates significantly increase cumulative dry weight yield and chlorophyll content of turfgrass leaf tissue. The increase in cumulative dry weight yield with increasing nitrogen rate coupled with a rapid increase in color as nitrogen increased suggest that the velvet bentgrass has a greater response to nitrogen addition at establishment compared with creeping bentgrass. Toward the end of the study, however, there was unexplained dieback in the greenhouse that affected the velvet bentgrass quality measures more than creeping bentgrass. The velvet bentgrass became slightly off-color and did not provide good quality after clipping (it had a matted and bruised appearance). Once this was observed across many of the high nitrogen treatments, the project was ended as to preserve experimental root data. However, had the project continued on for an extended period, it is possible this may have been the precursor to ammonium toxicity as a result of excessive nitrogen application (Barker et al.,
1966; van den Berg et al., 2005). Chlorosis has been previously observed in established velvet bentgrass and is thought to be a response to ammonium toxicity (Brilman, 2007, personal communication). However, no reports of this type of response have been noted during establishment. This phenomenon was not observed in Study 1 because it was shorter in duration and chlorosis started to appear only toward the end of the second study.

Turfgrass quality. Turfgrass species, root zone mixture, and nitrogen rate all affected turfgrass quality by the fifth week (Fig. 3). At Week 5, both of the bentgrasses grown on the $80: 20$ root zones were of higher quality than those on the $100 \%$ sand. Turfgrass quality also increased with nitrogen rate at Week 5 of the experiment with the velvet bentgrass on the 80:20 root zone having significantly higher quality ratings at the highest two nitrogen rates when compared with the velvet bentgrass on $100 \%$ sand root zones. By Week 10, there was a significant turfgrass species-by-nitrogen rate interaction present for quality as well as a root zone-by-nitrogen-rate interaction present. The quality of the velvet bentgrass cultivar was maximized at $0.48 \mathrm{~g} \mathrm{~N} / \mathrm{m}^{2} /$ week on the $80: 20$ root zone and at $0.96 \mathrm{~g} \mathrm{~N} / \mathrm{m}^{2} /$ week for the $100 \%$ sand, but a decline at the highest nitrogen rates was observed in both root zones. This effect was especially evident in the $100 \%$ sand root zone where there was a steeper drop in quality at the two highest nitrogen rates. At Week 10, the creeping bentgrass cultivar increased in quality to $1.9 \mathrm{~g} \mathrm{~N} / \mathrm{m}^{2} /$ week and stabilized. Although turfgrass quality encompasses a number of factors, including density, color, and leaf texture, color is likely the most influential factor and therefore these data may reflect the decrease in color in velvet bentgrass at the high nitrogen rates by Week 10 .

Root:shoot ratio. All main effects in the analysis of root:shoot ratio were highly significant (data not shown). In general, the root: shoot ratio decreased with increasing nitrogen rate. A turfgrass species-by-nitrogen-rate interaction was present and suggested that velvet bentgrass is much more sensitive to increasing nitrogen levels. Specifically, velvet bentgrass in the $100 \%$ sand root zone at the lowest nitrogen rate had a significantly higher root: shoot ratio than the 'L-93' creeping bentgrass grown on both root zones. Root:shoot ratio was also higher with the $100 \%$ sand root zone than the 80:20 root zone in both species. This could be a result of greater pore space and easier physical penetration with greater sand content.

Turfgrass cover. Turfgrass species, root zone, and nitrogen rate all significantly affected turfgrass cover at both Weeks 5 and 10 of the second study. The ratings at Week 5 (Fig. 4) indicate that there was an increase in percent turfgrass cover with nitrogen level to the $1.9 \mathrm{~g} \mathrm{~N} / \mathrm{m}^{2} /$ week rate, and after that, percent turfgrass cover leveled off. At Week 5 of the study, the 80:20 root zone had a higher percent turfgrass cover than the $100 \%$ sand root zone for both 'L-93' and 'SR7200' across all nitrogen rates. At the end of the experiment, both species of turfgrass on both root zones were relatively well filled in regardless of nitrogen rate. The exception was 'L-93' on the $100 \%$ sand root zone at the lowest nitrogen rate, which exhibited a significantly lower percent turf cover than all other treatments. Bigelow et al. (2001) and Murphy et al. (2005) showed that creeping bentgrass establishes faster on organically amended root zones. It is likely that in the case of our study that the 80:20 root zone retained more water close to the surface over the first few weeks. This factor may have enhanced germination and resulted in more rapid fill-in of the growing area. In addition, the peat in the 80:20 root zones may have assisted with nutrient uptake as a result of a synergistic effect of humic acid presence (Cooper et al., 1998). However, further research is required to confirm this because Cooper et al. (1998) found that the effect of humic acids on nutrient uptake was inconsistent. By the end of our second study, most root zone columns were close to having $100 \%$ turfgrass cover.

Establishment and maintenance requirements for velvet bentgrass have not been 


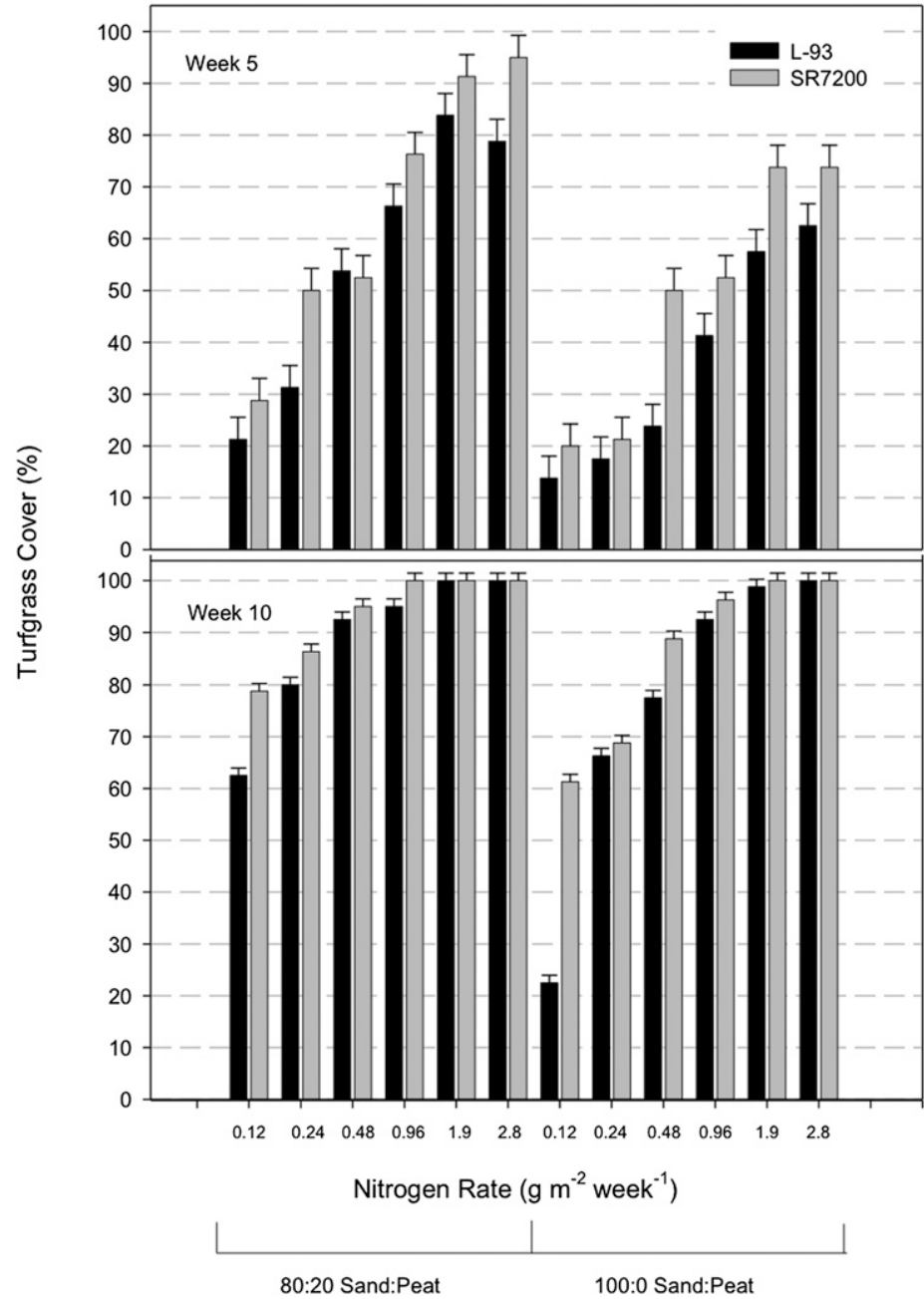

Fig. 4. The effect of nitrogen rate on turfgrass cover for 'L-93' creeping bentgrass and 'SR7200' velvet bentgrass grown in different substrates. The vertical bars represent the Fisher's protected LSD value, $\mathrm{LSD}_{0.05}=4.25$ for Week 5 and $\mathrm{LSD}_{0.05}=1.46$ for Week 10 . Treatment means are significantly different if they vary more than 4.25 and $1.46 \%$, respectively. LSD $=$ least significant difference.

extensively documented, although historic research has indicated that this species has shown promise as a putting green turf (Moneith and Welton, 1932). Currently it has application for use on putting greens as a result of disease resistance characteristics (Brilman and Meyer, 2000; Chakraborty et al., 2006) and potential tolerance to reduced nitrogen fertilization (Boesch and Mitkowski, 2007). We presented here two greenhouse studies that show that nitrogen rate and root zone are the driving factors behind turfgrass growth, rooting, and quality for both velvet bentgrass and creeping bentgrass at establishment.

\section{Literature Cited}

Barker, A.V., R.J. Volk, and W.A. Jackson. 1966. Root environment acidity as a regulatory factor in ammonium assimilation by the bean plant. Plant Physiol. 41:1193-1199.

Beard, J.B. 1973. Turfgrass: Science and culture. Prentice-Hall, Englewood Cliffs, NJ.

Beard, J.B. 2002. Turf management for golf courses. Ann Arbor Press, Chelsea, MI.

Bigelow, C.A., D.C. Bowman, D.K. Cassel, and T.W. Rufty, Jr. 2001. Creeping bentgrass response to inorganic soil amendments and mechanically induced subsurface drainage and aeration. Crop Sci. 41:797-805.

Boesch, B.P and N.A. Mitkowski. 2007. Management of velvet bentgrass putting greens. Appl. Turf. Sci. DOI:10.1094/ATS-2007-0125-01-RS.

Bowley, S.R. 2008. A hitchhiker's guide to statistics in plant biology. 2nd Ed. Any Old Subject Books, Guelph, Ontario, Canada.

Bowman, D.C., D.A. Devitt, M.C. Engelke, and T.W. Rufty, Jr. 1998. Root architecture affects nitrate leaching from bentgrass turf. Crop Sci. 38:1633-1639.

Brilman, L.A. and W.A. Meyer. 2000. Velvet bentgrass: Rediscovering a misunderstood turfgrass. Golf Course Mgt. 68:70-75.

Burrows, B. 2002. Pesticide ban coming to a golf course near you? GreenMaster 37:6-8-10.

Cavanaugh, M., E. Watkins, B. Horgan, and M. Meyer. 2011. Conversion of Kentucky bluegrass rough to no-mow, low-input grasses. Appl. Turf. Sci. DOI:10.1094/ATS-2011-0926-02-RS.

Chakraborty, N., T. Chang, M.D. Casler, and G. Jung. 2006. Response of bentgrass cultivars to Sclerotinia homoeocarpa isolates representing 10 vegetative compatibility groups. Crop Sci. 46:1237-1244.

Christians, N. 1998. Fundamentals of turfgrass management. John Wiley and Sons Inc., Hoboken, NJ.
Christians, N.E., D.P. Martin, and K.J. Karnok. 1981. The interrelationship among nutrient elements applied to calcareous sand greens. Agron. J. 73:929-932.

Christians, N.E., D.P. Martin, and J.F. Wilkinson. 1979. Nitrogen, phosphorus, and potassium effects on quality and growth of kentucky bluegrass and creeping bentgrass. Agron. J. 71:564567.

Cooper, R.J., C. Liu, and D.S. Fisher. 1998. Influence of humic substances on rooting and nutrient content of creeping bentgrass. Crop Sci. 38:1639-1644.

Cousineau, K. 2002. An update on pesticides. GreenMaster. 37:23.

DaCosta, M. and B. Huang. 2006a. Minimum water requirements for creeping, colonial, and velvet bentgrasses under fairway conditions. Crop Sci. 46:81-89

DaCosta, M. and B. Huang. 2006b. Osmotic adjustment associated with variation in bentgrass tolerance to drought stress. J. Amer. Soc. Hort. Sci. 131:338-344.

DeFrance, J.A., T.E. Odland, and R.S. Bell. 1952 Improvement of velvet bentgrass by selection. Agron. J. 44:376-378.

Dernoeden, P.H. 2002. Creeping bentgrass management-Summer stresses, weeds and selected maladies. John Wiley and Sons Inc., Hoboken, NJ.

Gerretsen, H.J. 2008. Bill 64-An act to amend the Pesticides Act to prohibit the use and sale of pesticides that may be used for cosmetic purposes. 8 Aug. 2011. <http://www.ontla.on.ca/bills/ bills-files/39_Parliament/Session1/b064ra.pdf $>$.

Hoagland, D.R. and D.I. Arnon. 1938. The water culture method for growing plants without soil. Circular 347 University of California College of Agriculture.

Johnson, P.G., R.T. Koenig, and K.L. Kopp. 2003. Nitrogen, phosphorus, and potassium responses and requirements in calcareous sand greens. Agron. J. 95:697-702.

Kaminski, J.E., P.H. Dernoeden, and C.A. Bigelow. 2004. Soil amendments and fertilizer source effects on creeping bentgrass establishment, soil microbial activity, thatch, and disease. HortScience 39:620-626.

Madison, J.H. 1962. Turfgrass ecology. Effects of mowing, irrigation and nitrogen treatments on Agrostis palustris Huds. 'Seaside' and Agrostis tenius Sibth. 'Highland' on population, yield, rooting, and cover. Agron. J. 54:407-412.

Markland, F.E. and E.C. Roberts. 1969. Influence of nitrogen fertilizers on Washington creeping bentgrass, Agrostis palustris Huds. I. Growth and mineral composition. Agron. J. 61:698-700.

Markland, F.E., E.C. Roberts, and L.R. Frederick. 1969. Influence of nitrogen fertilizers on Washington creeping bentgrass, Agrostis palustris Huds. II. Incidence of dollar spot, Sclerotinia homoeocarpa, infection. Agron. J. 61:701-705.

McCrimmon, J.N., H.A. Mills, and K.J. Karnok. 1992. Effect of $\mathrm{N}$-form on growth and nutrient content of creeping bentgrass. J. Plant Nutr. 15:1235-1252.

Miles, J. 1974. A note on the relation between phosphorus supply and the abundance of Agrostis canina ssp. Montana on a Southern English heath. J. Ecol. 62:355-358.

Moneith, J. and K. Welton. 1932. Putting tests upon bentgrasses. The Bulletin of the USGA Green Section. 12:224-227.

Morris, K.N. Undated. A guide to NTEP turfgrass ratings. 8 Aug. 2011. <http://www.ntep.org/ reports/ratings.htm\#tap>.

Murphy, J.A., J.A. Honig, H. Samaranayake, T.J. Lawson, and S.L. Murphy. 2001. Creeping 
bentgrass establishment on root zones varying in sand sizes. Int. Turfgrass Soc. Res. J. 9:573579.

Murphy, J.A., H. Samaranayake, J.A. Honig, T.J. Lawson, and S.L. Murphy. 2005. Creeping bentgrass establishment on amended-sand rootzones in two microenvironments. Crop Sci. 45: 1511-1520.

North, H.F.A. and T.E. Odland. 1934. Putting green grasses and their management. Rhode Island Agr. Expt. Sta. Bul. 245.

O'Connor, K. 2009. The effects of fertilizer application method on species composition of a putting green. MSc thesis, Univ. of Guelph, Guelph, Ontario, Canada.

Ontario Ministry of Agriculture, Food and Rural Affairs. 2005. Turfgrass management recommendations-Publication 384. Queens Printer for Ontario, Toronto, Ontario, Canada.

Paré, K. 2004. Nitrogen requirements and leaching potential of putting green grasses (Poa annua
L. ecotypes and Agrostis L. species). MSc thesis, Univ. Guelph.

Schlossberg, M.J. and K.J. Karnok. 2001. Root and shoot performance of three creeping bentgrass cultivars as affected by nitrogen fertility. J. Plant Nutr. 24:535-548.

Skogley, C.R. 1975. Fertilizer and topdressing management. USGA Green Section Record. 13:7-9.

Sprague, H.B. and E.E. Evaul. 1930. Experiments with turf grasses in New Jersey. New Jersey Agr. Expt. Sta. Bul. 497.

Throssel, C.S., G.T. Lyman, M.E. Johnson, and G.A. Stacey. 2009. Golf course environmental profile measures nutrient use and management and fertilizer restrictions, storage, and equipment calibration. Appl. Turf. Sci. DOI:10.1094/ATS2009-1203-01-RS

United States Golf Association Green Section Staff. 1993. USGA recommendations for putting green construction-1993 Revision. USGA Green Section Record. 31:1-3. van den Berg, L.J.L., E. Dorland, P. Vergeer, M.A.C. Hart, R. Bobbink, and J.G.M. Roelofs. 2005. Decline of acid-sensitive plant species in heathland can be attributed to ammonium toxicity in combination with low $\mathrm{pH}$. New Phytol. 166:551-564.

Vavrek, B. 1999. Bentgrass putting green establishment. USGA Green Section Record. 37 : $1-6$.

Waddington, D.V., T.R. Turner, J.M. Duich, and E.L. Moberg. 1978. Effect of fertilization on 'Penncross' creeping bentgrass. Agron. J. 70: 713-718.

Watkins, E., A.B. Hollman, and B.P. Horgan. 2010. Evaluation of alternative turfgrass species for low-input golf course fairways. HortScience 45: 113-118.

White, C.B. 2003. The birth of a putting green-A turf manager's guide for establishing a new putting green. USGA Green Section Record. 41: $1-6$. 